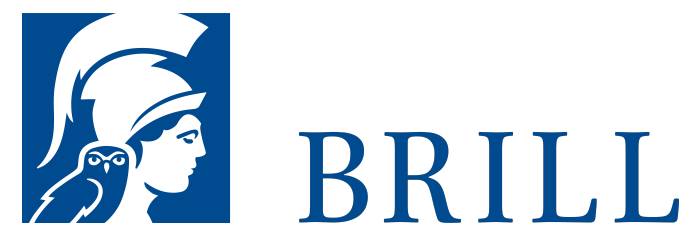

\title{
Briefe der Münchener Zeit
}

\section{Authors: Monika Fink-Lang and Joseph Görres}

Görres' Briefe der Münchner Zeit umfassen den Zeitraum von Ende 1827 bis zu seinem Tod 1848, also die letzte Phase seines facetten-reichen Lebens, in der er als Pro-fessor für 'Allgemeine und Litte-rär-geschichte' an der Univer-si-tät München wirkte und zum Vor-kämp-fer und Sprachrohr des Katho-lizismus in Deutschland wurde. Der Briefband, der mehr als 25o Briefe von Görres an verschiedene Adressaten umfasst, darunter etwa 100 bisher unveröffentlichte Stücke, bietet nicht nur Einblicke in den biographischen Kontext und die Genese der Werke der Münchner Zeit und ein Abbild des reichen Beziehungsgeflechts, das Görres mit Persönlichkeiten in ganz Deutschland und darüberhinaus verband, sondern auch einen intimen Blick auf den Menschen Görres, auf seine Familie und seinen Freundeskreis. Daneben bietet die Ausgabe über 500 zum Großteil bisher unveröffentlichte Briefe an Görres in Kurzregesten.

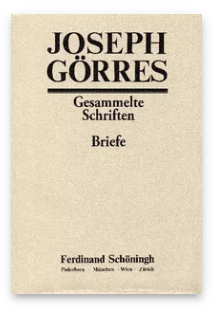

Pages: 727

Seiten

Language:

German

Subjects: Early

Modern History, History

Publisher: Brill | Schöningh

Series:

Joseph Görres -

Gesammelte

Schriften -

Briefe, Volume: 1

Görres -

Gesammelte

Schriften (alles),

Volume: 1

E-Book (PDF)

Released online:

22 Jun 2020

ISBN: 978-3-

657-76351-1

List price

USD $\$ 198.00$

Hardback

Publication date:

22 Jul 2009

ISBN: 978-3-

506-76351-8

List price

USD \$198.oo 
For more information see brill.com

Order information: Order online at brill.com +44330 333 0049 | customerservices@brill.com Submission information: brill.com/authors

Titles published by Brill | Fink, Brill | mentis or Brill | Schöningh: +49(o)715413279216| brill@brocom.de 